\title{
An Evidence Analysis Of The Exchange Rate Disconnect Puzzle In Indonesia
}

\author{
Agus Salim \\ School of Economics, Northeast Normal University, Changchun Jilin, China. \\ ags192@nenu.edu.cn \\ Ignatius Abasimi \\ School of Economics, Northeast Normal University, Changchun Jilin, China. \\ Long Vorlak \\ School of Economics, Northeast Normal University, Changchun Jilin, China.
}

\begin{abstract}
A dilemma in international macroeconomics that have been being empirical debating is Meese-Rogoff exchange rate disconnect as the persistent research finding of disengaging between exchange rate and macroeconomic fundamentals. This study analyses the evidence of the exchange rate disconnect puzzle of Indonesian Rupiah vis-á-vis the United States dollar. By using ARDL, the result showed that in the short-run, Dornbusch-Frankel sticky price model explains better the refusing of the puzzle evidence which provided macroeconomic fundamental that affect exchange rate movement. Nevertheless, in the long-run, Frenkel-Bilson flexible price model provide a little support in the refusing of the puzzle evidence.
\end{abstract}

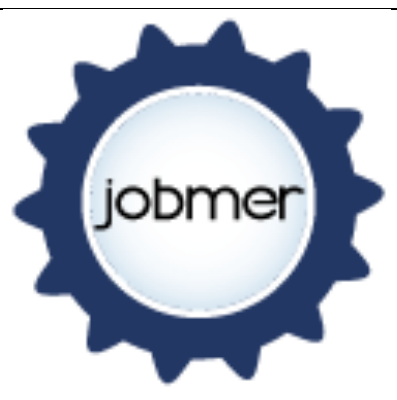

Journal of Business

Management and Economic Research

Vol.2, Issue.5, 2018

pp. $47-60$

Doi: 10.29226/TR1001.2018.33

Keywords: exchange rate, macroeconomic fundamentals, ARDL, sticky price, flexible price. 


\section{Introduction}

International finance interdependence that has been occurring creates an excellent variation effect towards the correlation of whole macroeconomic variables in several empirical studies, even it contrary to the theoretical concept. This instability correlation provides conundrums that have been debating, one of which is the relationship between the exchange rate and the macroeconomic fundamentals. Theoretically, the exchange rates volatility, in the long run, is determined by several macroeconomic fundamentals such as money supply, real income, real interest rate, inflation, trade balances and another significant variable (Lagana \& Sgro, 2007; Tawadros, 2016). Another result that is supporting the relationship between exchange rates and fundamentals which provided by Davreux and Engel (2002), Guo and Savickas (2005), and Abhyankar et al. (2005). They showed the result which concentered on the theoretical developments and explanations, the econometrics technique including data improvement, and the economic value of assessing the performance of these fundamental models.

Exchange rates determination which provided problems on international macroeconomics, is still not completely solved. Oppositely, the empirical evidence which builds by Meese \& Rogoff (1983) who studied the exchange rate determination with five independent variables, therefore, concluded that have no significant effect of the fundamental macroeconomics towards exchange rate of the dollar against Mark, Yen, and Pound. Furthermore, Cushman (2000) confirm that the discovery of this conundrum becomes a debating in international macroeconomic in some currency cases which so-called the exchange rate disconnect puzzle.

Recently an empirical study of Engel and West (2005) used the United States exchange rate against the other six members of the 'Group of Seven' (G7) are Canada, French, Germany, Italy, Japan, and the United Kingdom explained well-known the puzzle. In particular, which using quarterly data from 1974:1 until 2001:3 they found a little providing support of the fundamental variables such as relative money supply, output, inflation, and the interest rate on predicting changes of the United States floating exchange rates. Specifically, in multivariate specifications of the long run equilibrium relationship almost have no valid evidence of the monetary model and co-integration in only five out of the 24 equations in the bivariate setting of how exchange rates determined.

The purpose of this study is to investigate the evidence of Meese-Rogoff exchange rate disconnect puzzle the case of Indonesian Rupiah vis-á-vis the United States dollar using quarterly data from 1990.Q2-2017.Q1. The focal point of this study is to examine the primary determinants of the nominal exchange rate and macroeconomic fundamentals relationship in the form of flexible price monetary model of Frenkel (1976) and Bilson (1978) which compared to the sticky price monetary model of Dornbusch (1976) and Frankel (1978). In peculiar, this study tries to investigate the ability of macroeconomic variables to predict exchange rates movement in the short run and long run.

Following parts divide this study. In the second part would be presented the theoretical framework and previous study of flexible and sticky prices. The third would explain the methodological concept and econometric modelling. Moreover, the forth would be analysed the result of causality test and discussed the evidence of Indonesian exchange rate disconnect puzzle, while the last part would be concluding and policy recommendation.

\section{Literature Review}

In the early 1970s separated from World War II, most countries pegged their currency on the fixed exchange rates that cannot be divided by the Bretton Woods System. The system specifically created to avoid the speculation of the foreign exchange rates market. Afterwards, in 1973 system failed to maintain the mechanism of foreign exchange rates volatility after United States dollar devaluated inside the period. Lagana \& Sgro (2007) mentioned that the breaking down of the Bretton Woods System encouraged testing the exchange rate models using 
determination and their theoretical variable causality. The first empirical testing was directed to examine the validity of exchange rates which characterised by "flexible and sticky price" models.

\subsection{The Flexible-Price Monetary Approach: A Theoretical Framework}

The monetary model exchange rate determination with flexible price assumes that purchasing power parity condition holds when prices are perfectly flexible (Frenkel, 1976; Bilson, 1978). The condition of holding the purchasing power parity is following the equation:

$$
s_{t}=p_{t}-p_{t}^{f}
$$

Where, $s$ is the log of the spot exchange rate, described as the differential of home $p_{t}$ and foreign $p_{t}^{f}$ price levels, respectively. Based on the quantity theory of money, both of prices are determined by the equilibrium in the home and foreign country, respectively given in the following equation:

$$
\begin{aligned}
& p_{t}=m_{t}-\varphi y_{t}+\lambda i_{t}, \\
& p_{t}^{f}=m_{t}^{f}-\varphi y_{t}^{f}+\lambda i_{t}^{f},
\end{aligned}
$$

Where $m, y$, and $i$ represent the stock of money, real income, and interest rate respectively, and $f$ denotes the corresponding foreign country variable. Frenkel (1976) and Bilson (1978) assume that for this condition, the elasticity with respect to income, $\varphi$, and semi elasticity with respect to the interest rate, $\lambda$, are equal between the countries engaged. Substituting the equation (2) and (3) to the equation (1) yields the representation of the flexible price monetary model given in the following equation:

$$
s_{t}=\left(m_{t}-m_{t}^{f}\right)-\varphi\left(y_{t}-y_{t}^{f}\right)+\lambda\left(i_{t}-i_{t}^{f}\right) .
$$

Notably, in equation (4) states that a rise in home interest rate relative to the foreign interest rate leads to depreciation to the home currency. Thus, this condition holds the uncovered interest rate parity that the expected depreciation of home currency equal to the interest rate differential. Then the market will be aware to the expected inflation rates as holds in the condition of purchasing power parity implicitly given in the equation (1) which expected depreciation of home currency equal to the expected inflation rates differential (Frenkel, 1976). Henceforth, the differential interest rate equal to the expected inflation rates differential, which given in the following equation:

$$
\Delta s^{e}=i_{t}-i_{t}^{f}=\pi_{t}-\pi_{t}^{f}
$$

Substituting the equation (5) to the equation (4) yields the alternative representation of the flexible monetary price which following equation:

$$
s_{t}=\left(m_{t}-m_{t}^{f}\right)-\varphi\left(y_{t}-y_{t}^{f}\right)+\lambda\left(\pi_{t}-\pi_{t}^{f}\right) .
$$

Equation (6) states that the exchange rates, as the alternative price of money is determined by the differential of the stock of money, real income, and inflation rates. Notably, an increase in the home inflation rate relative to the foreign inflation rate will increase to a depreciation of the home currency.

To provide more useful a flexible price condition of monetary exchange rate determination of the equation (6) can be rewritten as an econometrically model:

$$
s_{t}=\alpha+\beta\left(m_{t}-m_{t}^{f}\right)+\varphi\left(y_{t}-y_{t}^{f}\right)+\lambda\left(\pi_{t}-\pi_{t}^{f}\right)+\varepsilon_{t}
$$


Where $\beta=1, \varphi=-1$, and $\lambda=1$. The equation (7) of the flexible price of the monetary model as earlier provided by Frenkel (1976) and Bilson (1978) has been widely estimated and become furthest model that will be examined in this study.

\subsection{The Sticky-Price Monetary Approach: A Theoretical Framework}

The monetary approach of the exchange rate determination model in sticky price states that only in the long run, purchasing power parity will hold, otherwise is unrealistic (Dornbusch, 1976; Frankel, 1978). The long-run condition of the purchasing power parity holding is following the equation:

$$
\overline{s_{t}}=p_{t}-p_{t}^{f}
$$

Where $\overline{s_{t}}$ indicate the log of the spot exchange rate in the long-run equilibrium. Thus, following the Fankel-Bilson equation (6) that provide a characterization of the long-run equilibrium:

$$
\overline{s_{t}}=\left(m_{t}-m_{t}^{f}\right)-\varphi\left(y_{t}-y_{t}^{f}\right)+\lambda\left(\pi_{t}-\pi_{t}^{f}\right) .
$$

In the short-run, the spot exchange rate can deviate from its equilibrium value; the market expects the spot rate to regress toward equilibrium at a rate proportional to the gap which following equation:

$$
\Delta s_{t}^{e}=-\theta\left(s_{t}-\overline{s_{t}}\right)+\left(\pi_{t}-\pi_{t}^{f}\right) .
$$

The equation (10) states that exchange rate expectations thrive the correspond to a simple regressive expectations model is modified to include secular rates of inflation. Substituting the uncovered interest parity in equation (5) into the equation (10) yields the representation for the gap of current and its equilibrium level of spot rate which following the equation:

$$
s_{t}-\overline{s_{t}}=-\frac{1}{\theta}\left[\left(i_{t}-\pi_{t}\right)-\varphi\left(i_{t}^{f}-\pi_{t}^{f}\right)\right]
$$

The equation (10) above states that the current exchange rate differs from its long-run rate in proportion to the real interest rate differential. Substituting the equation (9) into the equation (11) to acquire the exchange rate determination model with sticky price monetary condition, which following equation:

$$
s_{t}=\left(m_{t}-m_{t}^{f}\right)-\varphi\left(y_{t}-y_{t}^{f}\right)+\left(\lambda+\frac{1}{\theta}\right)\left(\pi_{t}-\pi_{t}^{f}\right)-\frac{1}{\theta}\left(i_{t}-i_{t}^{f}\right) .
$$

To provide more useful a sticky price condition of monetary exchange rate determination of the equation (11) can be rewritten as an econometrically model:

$$
s_{t}=\alpha+\beta\left(m_{t}-m_{t}^{f}\right)+\varphi\left(y_{t}-y_{t}^{f}\right)+\eta\left(\pi_{t}-\pi_{t}^{f}\right)+\gamma\left(i_{t}-i_{t}^{f}\right)+\varepsilon_{t}
$$

Where $\beta=1, \varphi=-1, \eta=\left(\lambda+\frac{1}{\theta}\right), \gamma=-\frac{1}{\theta}, \eta>\gamma$ in absolute terms. Based on equation (12) the sticky the price monetary model of Dornbusch (1976) and Frankel (1978) assume that the coefficient on the interest rate differential is not less than zero and the expected inflation differential, $\eta$, is equal to zero.

\subsection{Monetary Approach of the Exchange Rate Determination: The Empirical Framework}

The monetary approach in a different version that was employed by Frenkel and Koske (2004) investigated the wellness of this approach to explain the determination of the euro nominal exchange rate vis-á-vis six currencies. The maximum and eigenvalue tests showed that for the euro against currencies of Canada, Switzerland, Japan, Norway, and the UK, both of the tests indicate actively support of the fundamental variables to the engaged exchange rates at 1 percent 
significance level. Other alongside the results showed that for the exchange rate vis-á-vis US dollar provide cointegrating relationship at 20 percent significance level.

Engel and West (2005) examined six exchange rates of industrialised countries used cointegration to test the long-run relationship between the exchange rate and some fundamental variables such as relative money supplies, relative output, interest rate differential and inflation rate differential. Mainly they employed the standard Johansen and Juselius (1990) approach for the testing of the exchange rate determination and conducted become multivariate equation and the bivariate equation of the exchange rates for every country which engaged each other and every fundamental macroeconomic variable separately. They conclude that result explains the evidence of the puzzle that almost all of the fundamental variables except inflation rates provide a small explanation to the floating exchange rates.

Similar dataset to the Engel and West (2005), by using autoregressive distributed lag (ARDL) approach to the cointegration, Oskooee (2014) showed there was no evidence of the exchange rates disconnect puzzle in Finland, Italy, Portugal, France and Switzerland. The model provided a result that the exchange rates and fundamental monetary variables moved together in the longrun. Their employing of Granger causality test also confirmed the ARDL test that monetary fundamentals granger causes the exchange rates. Thus, they concluded the supporting of the monetary model that they employed.

\section{Research Method}

This study uses quarterly data from 1990 quarter two until 2017 quarter one. Data downloaded from the official site International Monetary Fund (IMF) and The Organisation for Economic Co-operation and Development (OECD). The dependent variable is the spot exchange rate of Indonesian Rupiahs per U.S. dollar $\left(s_{t}\right)$. Another four independent variables are differential of broad money using M3 of Indoensia and USA as a proxy of money supply differential $\left(m_{t}-\right.$ $m_{t}^{f}$ ), GDP growth differential between Indonesia and USA as proxy of relative income differential $\left(y_{t}-y_{t}^{f}\right)$, consumer price index as a proxy of price differential $\left(\pi_{t}-\pi_{t}^{f}\right)$, and interest rate differential $\left(i_{t}-i_{t}^{f}\right)$.

The analysis begins from estimating equation (7) of the flexible price model and equation (13) of sticky price model using Autoregressive Distributed Lag (ARDL), particularly bound testing approach to cointegration which developed by Pesaran et al. (2001). The ARDL also used by some empirically tests the validity of the monetary theories to exchange rate determination. ARDL used to analyse the existence of cointegration relationship between the exchange rates and the monetary fundamentals variable to discover the presence of the puzzle.

The requiring estimation before running the ARDL test is the Augmented Dickey-Fuller (ADF) Unit Root Test unit root to establish the stationarity of the variables. The cointegration testing of the relationship between the exchange rate and the fundamentals of Fenkel-Bilson flexible price monetary as the first model, we rewrite equation (7) in a constrained error-correction format which following bound test as outlined by the $\operatorname{ARDL}\left(n_{1}, n_{2}, n_{3}, n_{4}\right)$ which following equation:

$$
\begin{aligned}
\Delta s_{t}=\alpha & +\sum_{k=1}^{n_{1}} \emptyset_{k} \Delta s_{t-k}+\sum_{k=0}^{n_{2}} \beta_{k} \Delta\left(m_{t}-m_{t}^{f}\right)_{t-k}+\sum_{k=0}^{n_{3}} \varphi_{k} \Delta\left(y_{t}-y_{t}^{f}\right)_{t-k} \\
& +\sum_{k=0}^{n_{4}} \lambda_{k} \Delta\left(\pi_{t}-\pi_{t}^{f}\right)_{t-k}+\delta_{1} s_{t-1}+\delta_{2}\left(m_{t}-m_{t}^{f}\right)_{t-1}+\delta_{3}\left(y_{t}-y_{t}^{f}\right)_{t-1} \\
& +\delta_{4}\left(\pi_{t}-\pi_{t}^{f}\right)_{t-1}+\varepsilon_{t}
\end{aligned}
$$


The second is the cointegration relationship between the exchange rate and the fundamentals of Dornbusch-Frankel sticky price monetary model by rewriting the equation (13) in a constrained error-correction format which following bound test as outlined by the $\operatorname{ARDL}\left(n_{1}, n_{2}, n_{3}, n_{4}, n_{5}\right)$ which following equation:

$$
\begin{aligned}
\Delta s_{t}=\alpha & +\sum_{k=1}^{n_{1}} \emptyset_{k} \Delta s_{t-k}+\sum_{k=0}^{n_{2}} \beta_{k} \Delta\left(m_{t}-m_{t}^{f}\right)_{t-k}+\sum_{k=0}^{n_{3}} \varphi_{k} \Delta\left(y_{t}-y_{t}^{f}\right)_{t-k} \\
& +\sum_{k=0}^{n_{4}} \eta_{k} \Delta\left(\pi_{t}-\pi_{t}^{f}\right)_{t-k}+\sum_{k=0}^{n_{5}} \gamma_{k} \Delta\left(i_{t}-i_{t}^{f}\right)_{t-k}+\delta_{1} s_{t-1}+\delta_{2}\left(m_{t}-m_{t}^{f}\right)_{t-1} \\
& +\delta_{3}\left(y_{t}-y_{t}^{f}\right)_{t-1}+\delta_{4}\left(\pi_{t}-\pi_{t}^{f}\right)_{t-1}+\delta_{5}\left(i_{t}-i_{t}^{f}\right)_{t-1}+\varepsilon_{t}
\end{aligned}
$$

By estimating equation (14) and equation (15), the effects of each variable on the exchange rate in the short-run are inferred by the coefficient estimates attached to each of the first-differenced variables. The long-run effects are gained by the estimates of $\delta_{1}-\delta_{4}$ (for Fenkel-Bilson flexible price monetary model) and $\delta_{1}-\delta_{5}$ (Dornbusch-Frankel sticky price monetary model) which are normalized by $\delta_{1}$. Specifically, by using F-test examine the existence of long-run relationship, test the null hypothesis of no level relationship (no cointegration).

Mainly, Pesaran et al. (2001) provide two sets critical value in the stationary testing which applied irrespective of whether the variables are $I(1)$ or $I(0)$. An upper bound critical value assumes all variables are $I(1)$ and $I(0)$ for the all variables are lower bound critical value. If the calculated F-statistic is above the upper bound, then all variables are jointly significance longrun cointegration indicated, respectively to the lower bound of calculated F-statistic. On the other case, if the calculated F-statistic lies between these two bound, the result is inconclusive, and we can use an alternative test by forming lagged error correction term of the linear combination of lagged level variables in equation (14) of Fenkel-Bilson flexible price monetary model. The model is then re-estimated using the same number of optimum lags derived from the $\operatorname{ARDL}\left(n_{1}, n_{2}, n_{3}, n_{4}\right)$ which following equation:

$$
\begin{aligned}
\Delta s_{t}=\alpha & +\sum_{k=1}^{n_{1}} \emptyset_{k} \Delta s_{t-k}+\sum_{k=0}^{n_{2}} \beta_{k} \Delta\left(m_{t}-m_{t}^{f}\right)_{t-k}+\sum_{k=0}^{n_{3}} \varphi_{k} \Delta\left(y_{t}-y_{t}^{f}\right)_{t-k} \\
& +\sum_{k=0}^{n_{4}} \lambda_{k} \Delta\left(\pi_{t}-\pi_{t}^{f}\right)_{t-k}+\rho E C M_{t-1}+\varepsilon_{t},
\end{aligned}
$$

Giving the similar treatment for the equation (15) of Dornbusch-Frankel sticky price monetary model, the model is then re-estimated using the same number of optimum lags derived from the $\operatorname{ARDL}\left(n_{1}, n_{2}, n_{3}, n_{4}, n_{5}\right)$ which following equation:

$$
\begin{aligned}
\Delta s_{t}=\alpha & +\sum_{k=1}^{n_{1}} \emptyset_{k} \Delta s_{t-k}+\sum_{k=0}^{n_{2}} \beta_{k} \Delta\left(m_{t}-m_{t}^{f}\right)_{t-k}+\sum_{k=0}^{n_{3}} \varphi_{k} \Delta\left(y_{t}-y_{t}^{f}\right)_{t-k} \\
& +\sum_{k=0}^{n_{4}} \eta_{k} \Delta\left(\pi_{t}-\pi_{t}^{f}\right)_{t-k}+\sum_{k=0}^{n_{5}} \gamma_{k} \Delta\left(i_{t}-i_{t}^{f}\right)_{t-k}+\rho E C M_{t-1}+\varepsilon_{t} .
\end{aligned}
$$


In this new specification, one can examine the direction and speed of adjustment in the model following any short-run disequilibrium by examining the sign and significance of the $E C M_{t-1}$ coefficient. The ECM basically links the long-run equilibrium implied by the cointegration relationship with the short-run adjustment process describing the mechanism by which the variables react following any shock from the long-run equilibrium. In the context of equation (16) and (17) above, a negative and significant $\widehat{\rho}_{l}$ indicates adjustment of the exchange rate toward the long-run equilibrium following any short-run disequilibrium. Finally, the higher the absolute value of $\widehat{\rho}_{l}$, the faster the adjustment process or the convergence rate.

\section{Result and Discussion}

The analysis begins with the ensuring of the variables are either $I(0)$ or $I(1)$ to know that there is no series under that consideration using Augmented Dickey-Fuller unit roots test. The result of the stationary using unit roots test in both models is estimated and presented in the table 1:

Table 1. Unit Roots Test Result

\begin{tabular}{lccccc}
\hline \multirow{2}{*}{ Stationary level } & \multicolumn{5}{c}{ Variables } \\
& $\left(\boldsymbol{s}_{\boldsymbol{t}}\right)$ & $\left(\boldsymbol{m}_{\boldsymbol{t}}-\boldsymbol{m}_{\boldsymbol{t}}^{\boldsymbol{f}}\right)$ & $\left(\boldsymbol{y}_{\boldsymbol{t}}-\boldsymbol{y}_{\boldsymbol{t}}^{\boldsymbol{f}}\right)$ & $\left(\boldsymbol{\pi}_{\boldsymbol{t}}-\boldsymbol{\pi}_{\boldsymbol{t}}^{\boldsymbol{f}}\right)$ & $\left(\boldsymbol{i}_{\boldsymbol{t}}-\boldsymbol{i}_{\boldsymbol{t}}^{\boldsymbol{f}}\right)$ \\
\hline Level & -1.6388 & 4.0639 & $-6.7886^{* * *}$ & $-3.0284^{* *}$ & $-2.9301^{* *}$ \\
First Difference & $-7.7313^{* * *}$ & $-3.7506^{* * *}$ & $-15.925 * * *$ & $-5.9818^{* * *}$ & $-5.7179 * * *$ \\
\hline
\end{tabular}

An asterisk symbol showed the rejection of the null-hypothesis at $* * *=(1 \%), * *=(5 \%)$, and

$*=(10 \%)$

The table 1 above reports the result of the unit roots test both in level and first difference. Since in stationary test, the probability of t-statistic should be lower compared to the $1 \%, 5 \%$, and $10 \%$ significance level. The table showed that output differential, inflation differential, and interest rate differential variable being stationer in level. However, in the first difference level, all of the variables are stationary by rejecting the null hypothesis at $1 \%$ error term level. In particular, since the test conducted under first differences, can be concluded that there are no unit roots in first differences, and so each of the series must be either $I(0)$ or $I(1)$.

After known the result of the stationary test, the estimation proceeds to the next step which is the cointegration relationship that estimates equation (7) of monetary model and equation (13) of Dornbusch-Frankel sticky price monetary model. These estimated models followed by residual diagnostics such as serial correlation and homoscedasticity result which presented in table 2 .

In the testing of the autocorrelation using Breusch-Godfrey Serial Correlation LM test apply two lags with the null hypothesis is no serial correlation. Since the probability of F-statistic 0.1567 for Frenkel-Bilson flexible price model and 0.4464 for Dornbusch-Frankel sticky price model are higher than the significance level, the null hypothesis failed to reject. It implies that residuals of both models are serially uncorrelated. Similarly testing for residual homoscedasticity, the Breusch-Pagan-Godfrey used the null-hypothesis is homoscedasticity. The result shows that the probability of estimated $\mathrm{F}$ is 0.0000 for Frenkel-Bilson flexible price model and 0.4464 for Dornbusch-Frankel sticky price model which lower than significance level even $1 \%$. Thus, the residual is heteroskedastic in both of model estimated. The result of the residual test showed in the table of Appendix 1.

To test the presence of cointegration used in examining the null hypothesis states that no levels of relationship. The analysis focuses on the result of F-statistic comparing to the $I(0)$ and $I(1)$ critical value bound using the technique as mentioned in the previous section. The result of $\mathrm{F}$ Bound Test which presented in the following section. 
The result showed that F-statistics of both models are higher than $I(1)$ bound critical value in all significance level. It implies that the null hypotheses of both models are rejected. The result can be concluded that there is long-run cointegration between the exchange rates and macroeconomic fundamentals both in the Frenkel-Bilson flexible price model and DornbuschFrankel sticky price model. The empirical result of analysing equation (7) of Frenkel-Bilson flexible price monetary model and equation (13) of Dornbusch-Frankel sticky price monetary model states the relationship between exchange rate and each fundamental macroeconomic variable in both models to accompany the cointegration result above.

Figure in appendix 2 shows the parameter instability using CUSUM and CUSUM of square tests for each estimated model. Figure 1(a) shows that parameter of Frenkel-Bilson flexible price model estimator satisfies the stability requirement which CUSUM graph inside 5\% significance boundary so is the figure 1(c) which provide a parameter of Dornbusch-Frankel sticky price model estimator. Nevertheless, figure 1(b) shows the failing of CUSUM of square requirement satisfying, which the graph shows the line of CUSUM of the square is outside of 5\% significance boundary along after 1998 and before 2002. However, figure 1(d) shows that requirement stability of Dornbusch-Frankel sticky price model using CUSUM of the square test is satisfied. The F-Bound test result summaries in table 2.

Table 2. F-Bound Test Result

\begin{tabular}{lcccc}
\hline \multicolumn{1}{c}{ Models } & F-statistic & Signif. Level & $\boldsymbol{I}(\mathbf{0})$ & $\boldsymbol{I}(\mathbf{1})$ \\
\hline \multirow{2}{*}{ Fenkel-Bilson Flexible } & & $10 \%$ & 2.37 & 3.2 \\
Price & 6.381322 & $5 \%$ & 2.79 & 3.67 \\
& & $2.5 \%$ & 3.15 & 4.08 \\
& & $1 \%$ & 3.65 & 4.66 \\
Dornbusch-Frankel & \multirow{2}{*}{$* 621824$} & $10 \%$ & 2.2 & 3.09 \\
Sticky Price & & $2.5 \%$ & 2.65 & 3.49 \\
& & $1 \%$ & 2.88 & 3.87 \\
& & & 3.29 & 4.37 \\
\hline
\end{tabular}

The presentation of the result of autoregressive distributed lag which assessed the null hypothesis that there is no correlation between spot exchange rate and fundamental macroeconomic variables showed in table 3. In the form of Flexible-Price model, differential money supplies stem correctly signs in lag zero, and opposite sign in the lag 1 with both coefficients are not statistically significant. Looking at the real income differential variable which produced four lags have correctly negative sign except in the lag three with all of the coefficients are statistically significant. This variable correctly confirms Frenkel (1976) and Bilson (1978) who earlier render the flexible price model of monetary exchange rate model and. Since spot exchange rate used in this study is the value of Indonesian Rupiahs per one U.S. dollar. It states that the higher of the spot exchange rates value, the more depreciate Indonesian Rupiahs towards U.S. dollar. Bilson (1978) and Rogoff (1999) portray the coefficient of real income variable both in the home and the foreign country as the income elasticity of demand. Thus, a rise in the real income in Indonesia will increase domestic money demand then decrease the value of spot exchange rates which indicates an appreciation of Indonesian Rupiahs towards U.S. dollar as high as the rate of income elasticity of demand of each lag. 
Table 3. ARDL Estimation Result

\begin{tabular}{|c|c|c|c|c|}
\hline \multirow[b]{3}{*}{$\begin{array}{l}\text { ARDL } \\
\text { Estimates }\end{array}$} & \multicolumn{2}{|c|}{$\begin{array}{c}\text { Frenkel-Bilson Flexible Price } \\
\text { Model }\end{array}$} & \multicolumn{2}{|c|}{$\begin{array}{c}\text { Dornbusch-Frankel Sticky Price } \\
\text { Model }\end{array}$} \\
\hline & \multicolumn{2}{|c|}{$(1,1,4,2)$} & \multicolumn{2}{|c|}{$(1,1,4,0,3)$} \\
\hline & Coefficient & $\begin{array}{l}\text { Standard } \\
\text { Error }\end{array}$ & Coefficient & Standard Error \\
\hline$(C)$ & $0.294714 * * *$ & 0.093430 & $0.310525^{* *}$ & 0.150850 \\
\hline$\left(s_{t-1}\right)$ & $0.976577 * * *$ & 0.009605 & $0.976609 * * *$ & 0.014772 \\
\hline$\left(m_{t}-m_{t}^{f}\right)$ & 0.012724 & 0.008026 & $0.013100^{*}$ & 0.007048 \\
\hline$\left(m_{t-1}-m_{t-1}^{f}\right)$ & -0.013080 & 0.008355 & $-0.013523^{*}$ & 0.007277 \\
\hline$\left(y_{t}-y_{t}^{f}\right)$ & $-0.025406 * * *$ & 0.005867 & $-0.026571^{* * *}$ & 0.004851 \\
\hline$\left(y_{t-1}-y_{t-1}^{f}\right)$ & $-0.027989 * *$ & 0.013967 & $-0.019676^{* * *}$ & 0.004845 \\
\hline$\left(y_{t-2}-y_{t-2}^{f}\right)$ & $-0.019069 * * *$ & 0.004919 & $-0.018688 * * *$ & 0.006183 \\
\hline$\left(y_{t-3}-y_{t-3}^{f}\right)$ & $0.014776^{*}$ & 0.008006 & 0.009306 & 0.006603 \\
\hline$\left(y_{t-4}-y_{t-4}^{f}\right)$ & $-0.013184 * * *$ & 0.003441 & $-0.026707 * * *$ & 0.005357 \\
\hline$\left(\pi_{t}-\pi_{t}^{f}\right)$ & -0.008519 & 0.006957 & $-0.007397 * * *$ & 0.001798 \\
\hline$\left(\pi_{t-1}-\pi_{t-1}^{f}\right)$ & 0.008194 & 0.009712 & & \\
\hline$\left(\pi_{t-2}-\pi_{t-2}^{f}\right)$ & -0.005634 & 0.004475 & & \\
\hline$\left(\boldsymbol{i}_{t}-i_{t}^{f}\right)$ & & & $0.042785^{* * *}$ & 0.008154 \\
\hline$\left(i_{t-1}-i_{t-1}^{f}\right)$ & & & $-0.070540 * * *$ & 0.013357 \\
\hline$\left(i_{t-2}-i_{t-2}^{f}\right)$ & & & $0.051343 * * *$ & 0.013050 \\
\hline$\left(i_{t-3}-i_{t-3}^{f}\right)$ & & & $-0.023234 * * *$ & 0.008209 \\
\hline F-Statistic & $\begin{array}{c}614.5689 \\
{[0.000000]}\end{array}$ & & $\begin{array}{c}731.8937 \\
{[0.000000]}\end{array}$ & \\
\hline $\operatorname{Adj} \cdot R^{2}$ & 0.984968 & & 0.989276 & \\
\hline$E C$ & $-0.023423 * * *$ & 0.004059 & $-0.023391 * * *$ & 0.003165 \\
\hline Long-Run Coef & nt Estimate & & & \\
\hline$\left(m_{t}-m_{t}^{f}\right)$ & -0.015177 & 0.020065 & -0.018059 & 0.023745 \\
\hline$\left(y_{t}-y_{t}^{f}\right)$ & $-3.025669 * *$ & 1.183554 & -3.519905 & 2.189758 \\
\hline$\left(\pi_{t}-\pi_{t}^{f}\right)$ & $-0.254432 * *$ & 0.117682 & -0.316239 & 0.224810 \\
\hline$\left(i_{t}-i_{t}^{f}\right)$ & & & 0.015097 & 0.132527 \\
\hline
\end{tabular}

Figures reported in the parenthesis ( ) are selected model of ARDL estimation, parenthesis [ ] is a probability of $\mathrm{F}$-statistic. An asterisk $* * *, * *$, and * indicates rejection of the null hypothesis at 1,5 , and 10 percent of significance level respectively.

The estimated of expected inflation rates differential variable which constructed in two lags shows that almost all lags refute the hypothesis of the Frenkel-Bilson flexible price monetary model which given in the equation (6) omitting the lag one. This result of coefficient's trend represents the price elasticity of demand is contrary to the spot exchange rate variable. A rise in expected inflation in Indonesia following the decreasing of demand for money thereupon should depreciate the Indonesian Rupiahs towards U.S. dollar. Nevertheless, this study refuses the model which adopted from Frenkel (1976) and Bilson (1978). Correctly strengthen the trend result, all of the lags yielded in the expected inflation rates differential variables are declining in 
the rejection of null hypothesis which involves that the expected inflation rates differential did not alter the exchange rates movement of Indonesian Rupiahs towards U.S. dollar.

In the form of Dornbusch-Frankel sticky price model, lag one of spot exchange rate variable itself statistically significant affect the spot exchange rates movement with a positive sign of the coefficient. Contrasting to the estimation result of the Frenkel-Bilson flexible price model, almost all of variables significantly affect the exchange rate movement with the variability of significance level. Differential money supply has similar trace relative to the previous model though in this model both of variable form statistically significant affect the spot exchange rate movement in 90 percent confidence level. Lag zero of differential money supply variable provides the appropriate sign which involves that rising in the money supply in Indonesia will increase the value of spot exchange rates of Indonesian Rupiahs per U.S. dollar which means more depreciate Indonesian Rupiahs towards U.S. dollar. This result affirmatively confirms Bahmani-Oskooee (2014) which provided a similar sign in of the exchange rates of New Zealand vis-á-vis the exchange rates of Canada, French, Germany, Italy, Japan and U.K. Albeit the other lag provides inverse version confirm along with Chou (2017) in his all counterpart sample countries.

Entirely coincidental to the previous model, real income differential verifies the result of the study of Rapach and Wohar (2002), Engel and West (2005), and Tawadros (2016). Real income differential variable in almost all of lags statistically significant affect the exchange rates movement of Indonesian Rupiahs vis-á-vis U.S. dollar. The sign of the coefficients is proved the expected sign of the model expressly the equation (13). Lag for inflation rate differential changed from two lags become zero lag in the sticky price model by statistically significant affecting the exchange rate movements. However, it is providing inverse coefficient's narrow. As mentioned in the Dornbusch (1976) and Fankel (1978) a raising in the expected inflation conforming by raising in the domestic money demand should cause an appreciation. In this case, an increase in the domestic expected inflation rate alongside following the decreasing of money demand derive an appreciation of Indonesian Rupiahs by decreasing the value of Indonesian Rupiahs per one U.S. dollar. This result confirms Frenkel and Koskee (2004) oppositely for all their counterpart exchange rate countries.

Interest rate differential variable as the central statement of the Dornbusch-Frankel sticky price model confirms the significant effect on the dependent variable in all lags resulted. Nevertheless, the sign of coefficients divided into different narrow. In the lag one and three have corrected sign which confirms Frankel (1978) stated that the increase of the increase of domestic interest rate following by attracting more capital inflow would appreciate the exchange rates movement or decreasing value of Indonesian Rupiahs per U.S. dollar. Other two lags provide opposite sign.

As expected, the error correction term variable which produced by regression of the equation (16) and equation (17) showed in table 3 implies an associated coefficient estimate of -0.023423 for the Frenkel-Bilson flexible price model and -0.023391 for the Dornbusch-Frankel sticky price model. This entail that about $2.34 \%$ of every movement into disequilibrium are corrected for within one period of the Frenkel-Bilson flexible price model and Dornbusch-Frankel sticky price model. Moreover, both of model give highly significant effect in error correction variable towards exchange rate movement.

In the long run, no one macroeconomic fundamental variables of Dornbusch-Frankel sticky price model are statistically significant effect the exchange rates movement. Nevertheless, in the Frenkel-Bilson flexible price model only money supply differential variable showed its relationship to the dependent variable. Money supply differential provides a negative sign in both models. The increase in demand for money in home market will decrease the value of home currency per foreign currency means that appreciating of Indonesian Rupiahs. This result confirms the backbone of both models. 
Figure 1 showed the movement of the exchange rate and fundamental macroeconomic variables which analysed in this study. Money supply both in Indonesia and USA moved together in the observed period following the increase of the exchange rate of Indonesian Rupiahs per U.S. dollar. A high bounce of exchange rates in 1997 followed by a little bit increasing in the money supply in Indonesia. In 2011 money supply in Indonesia move higher than in USA with a small appreciation of Indonesian Rupiahs towards U.S. dollar. The movements between these variables in the figure confirmed by the result of Dornbusch-Frankel sticky price model in the short-run estimated. Alongside with the figure 1(a), GDP growth in Indonesia moved following the exchange rate appeared clearly in 1997 period. The sharply depreciated to the U.S. dollar, Indonesian Rupiah move together with decreasing of the GDP growth in Indonesia. It confirmed the ARDL estimation result that both models showed a significant correlation between exchange rates and income real which using proxy GDP growth except Dornbusch-Frankel sticky price model in the long-run equation.

Figure 1. Exchange Rates and Fundamental Macroeconomic Variables Movement
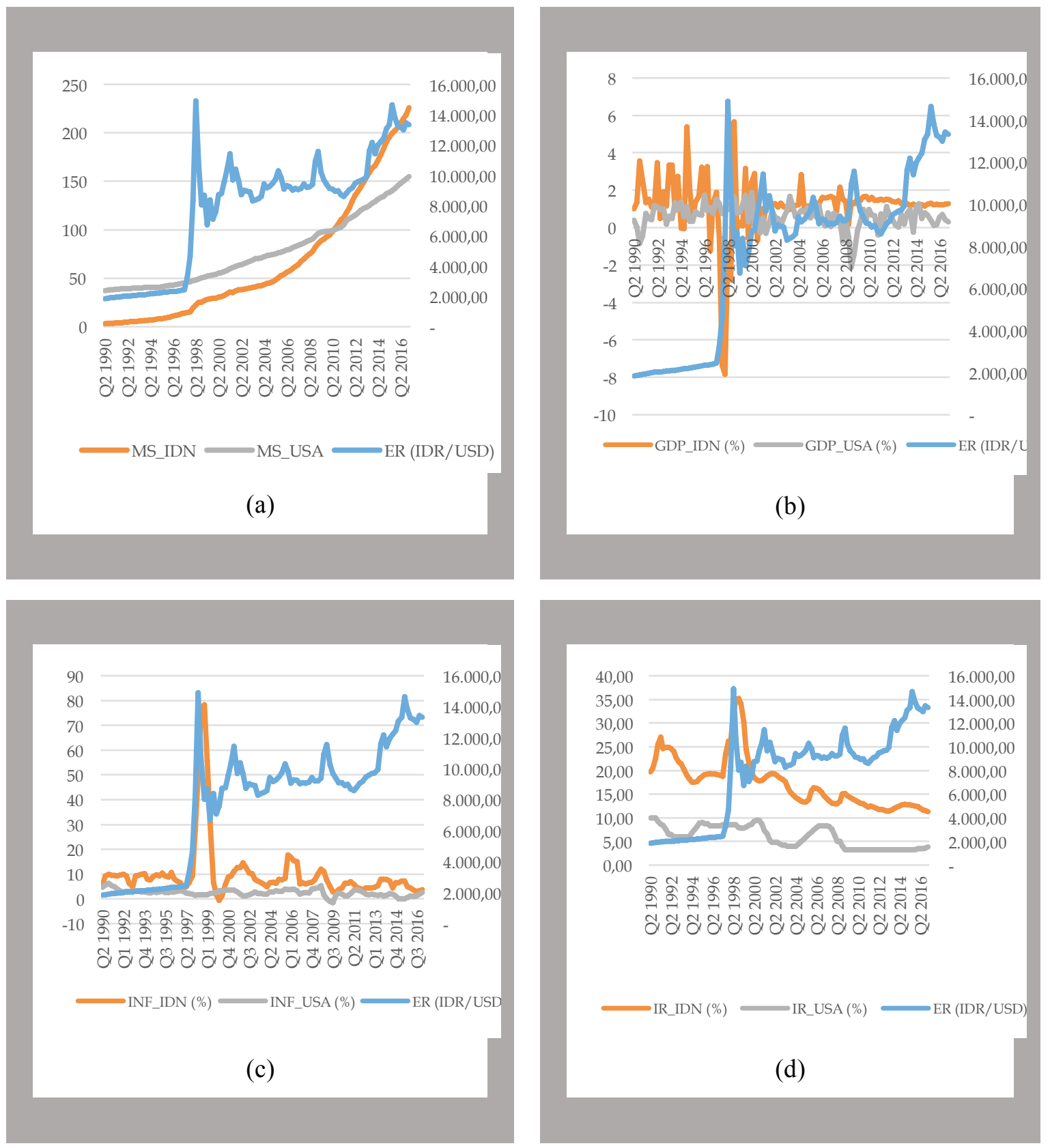
(a) exchange rates and money supplies movement; (b) exchange rates and GDP growths movement; (c) exchange rates and inflations movement; and (d) exchange rates and interest rates movement.

Another variable is inflation in Indonesia which moved together with exchange rates, particularly in the Asian financial crisis period. Nevertheless, afterwards in the post-crisis period the inflation rate sharply dropped become negative with a small decreasing of exchange rates towards U.S. dollar. The unique shape in figure 1(d) which showed the opposite movement between interest rate and exchange against U.S. dollar in Indonesia. Before crisis period interest rate decreased nevertheless the Indonesian Rupiahs had a small depreciation. In the post-crisis period, the depreciation of Indonesian Rupiahs towards U.S. dollar following the decreasing of interest rate. This interest rate - exchange rate figure confirms the estimation result of Dornbusch-Frankel sticky price model in the short-run equation.

\section{Conclusion}

In recent studies, the exchange rate determination analysed the exchange rate disconnect puzzle with some factors determined. This study operates the relatively new in the estimation technique with comparing two models as a backbone of the puzzle contributing. This study provides some conclusion such as the Dornbusch-Frankel sticky price model provide a more significant correlation between exchange rate and macroeconomic fundamental in the short-run rather than in the long-run. Moreover, another model is Frenkel-Bilson flexible price model that provides a little groundwork for the exchange rate and fundamental macroeconomic relationship either in the short-run or the long-run. Although, both models produce the same percentage movement into disequilibrium. Based on the coefficient's sign of the relative income differential which both models either in the short-run or in the long-run provide correctly influence into exchange rate movement. The finding of this study showed that the GDP growth should be used as a primary tool in the full filling the understanding of exchange rate determination.

\section{References}

Abhyankar, A., Sarno L. \& Valente, G. 2005. Exchange Rates and Fundamentals: Evidence on the Economic Value of Predictability. Journal of International Economics, 66 (2): 325-348. doi: 10.1016/j.jinteco.2004.09.003.

Bilson, J. F. O. 1978. The Monetary Approach to the Exchange Rate: Some Empirical Evidence. IMF Staff Papers, 25 (1): 48-75. doi: 10.2307/3866655.

Chou Y.-H. 2017. Understanding the sources of the exchange rate disconnect puzzle: A variance decomposition approach. International Review of Economics and Finance (2017), doi: 10.1016/j.iref.2017.10.029.

Cushman, D. O. 2000. The Failure of the Monetary Exchange Rate Model for the Canadian-U.S. Dollar. Canadian Journal of Economics, 33 (3): 591-603. doi: 10.1111/0008-4085.00031.

Devereux, M. \& Engel, C. 2002. Exchange Rate Pass-Through, Exchange Rate Volatility, and Exchange Rate Disconnect. Journal of Monetary Economics, 49 (5): 913-940. doi: 10.1016/s0304-3932(02)00130-7.

Dornbusch, R. 1976. Expectations and Exchange Rate Dynamics. Journal of Political Economy, 84 (6): 1161-1176. doi: 10.1086/260506.

Engel, C. \& West, K. D. 2005. Exchange Rates and Fundamentals. Journal of Political Economy. 113 (3): 485-517. doi: 10.1086/429137. 
Frenkel, J. A. 1976. A Monetary Approach to the Exchange Rate: Doctrinal Aspects and Empirical Evidence. The Scandinavian Journal of Economics, 78 (2): 200-224. doi: $10.2307 / 3439924$.

Frenkel, M. \& I. Koske. 2004. How Well Can Monetary Factors Explain the Exchange Rate of the Euro? Atlantic Economic Journal, 32 (3): 232-243. doi: 10.1007/BF02299441.

Guo, H. and Savickas, R. 2005. Foreign Exchange Rates Don't Follow A Random Walk. The Federal Reserve Bank of St. Louis Working Paper, 2005-025.

Lagana G. \& Sgro, P. M. 2007. The Exchange Rates Disconnect Puzzle: A Resolution? AsiaPacific Journal of Accounting \& Economics, 14 (2007): 43-68.

Meese, R. A. \& Rogoff, K. 1983. Empirical Exchange Rate Models of the Seventies: Do They Fit Out Sample? Journal of International Economics 14 (1983): 3-24.

Oskooee, M. B., Hosny, A., \& Kishor, N. K. 2014. The exchange rate disconnect puzzle revisited. International Journal of Finance and Economics, 20 (2): 126-137.

Pesaran M. H., Shin, Y., Smith, R. J. 2001. Bounds Testing Approaches to the Analysis of Level Relationships. Journal of Applied Econometrics, 16 (3): 289-326. doi: 10.1002/(ISSN)1099-1255.

Rapach, D. E., and M. E. Wohar. 2002. Testing the Monetary Model of Exchange Rate Determination: New Evidence from a Century of Data. Journal of International Economics, 58 (2): 359-385. doi: 10.1016/S0022-1996(01)00170-2.

Rogoff, K. S. 1999. Monetary Models of Dollar/Yen/Euro Nominal Exchange Rates: Dead or Undead? The Economic Journal, 109: F655-F659. doi: 10.1111/1468-0297.00477.

Tawadros, G. B. 2016. Revisiting the Exchange Rates Disconnect Puzzle. Applied Economics, 49 (36): 3645-3668. doi: 10.1080/00036846.2016.1265077. 


\section{Appendixes}

Appendix 1. Residual Diagnostic Test Result

\begin{tabular}{lcccc}
\hline \multirow{2}{*}{ Models } & \multicolumn{2}{c}{ Autocorrelation Test } & \multicolumn{2}{c}{ Homoscedasticity Test } \\
& F-statistic & Prob. F & F-statistic & Prob. F \\
\hline $\begin{array}{l}\text { Fenkel-Bilson } \\
\text { Flexible Price }\end{array}$ & 1.891845 & $0.1567^{*}$ & 9.857178 & 0.0000 \\
$\begin{array}{l}\text { Dornbusch-Frankel } \\
\text { Sticky Price }\end{array}$ & 0.813959 & $0.4464^{*}$ & 2.400401 & 0.0080 \\
\hline
\end{tabular}

An asterisk symbol showed the rejection of the null hypothesis at $1 \%, 5 \%$, and $10 \%$.

Appendix 2. Recursive Stability Diagnostic

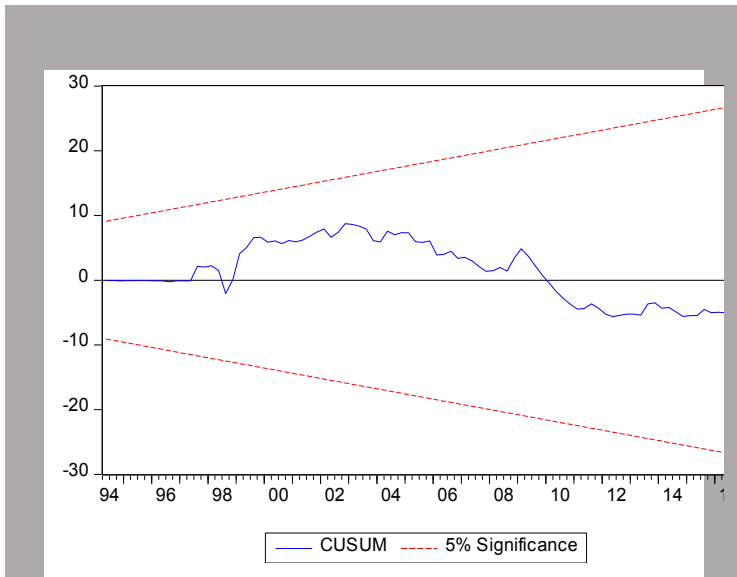

(a)

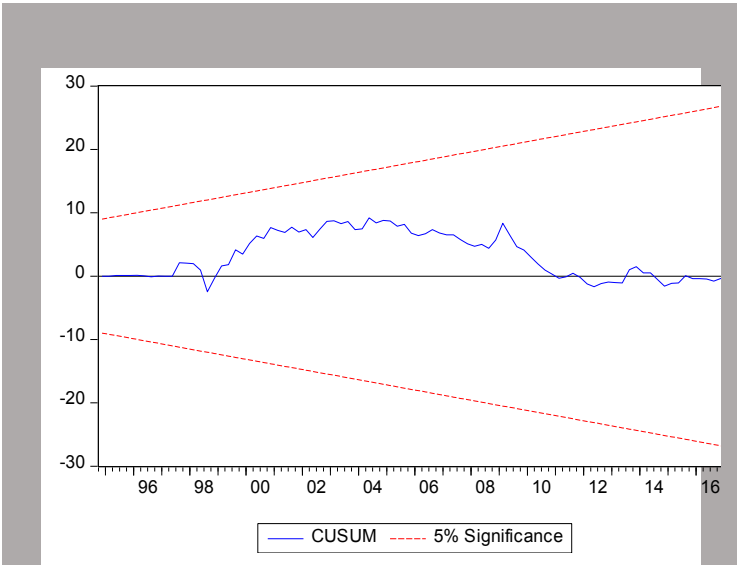

(c)
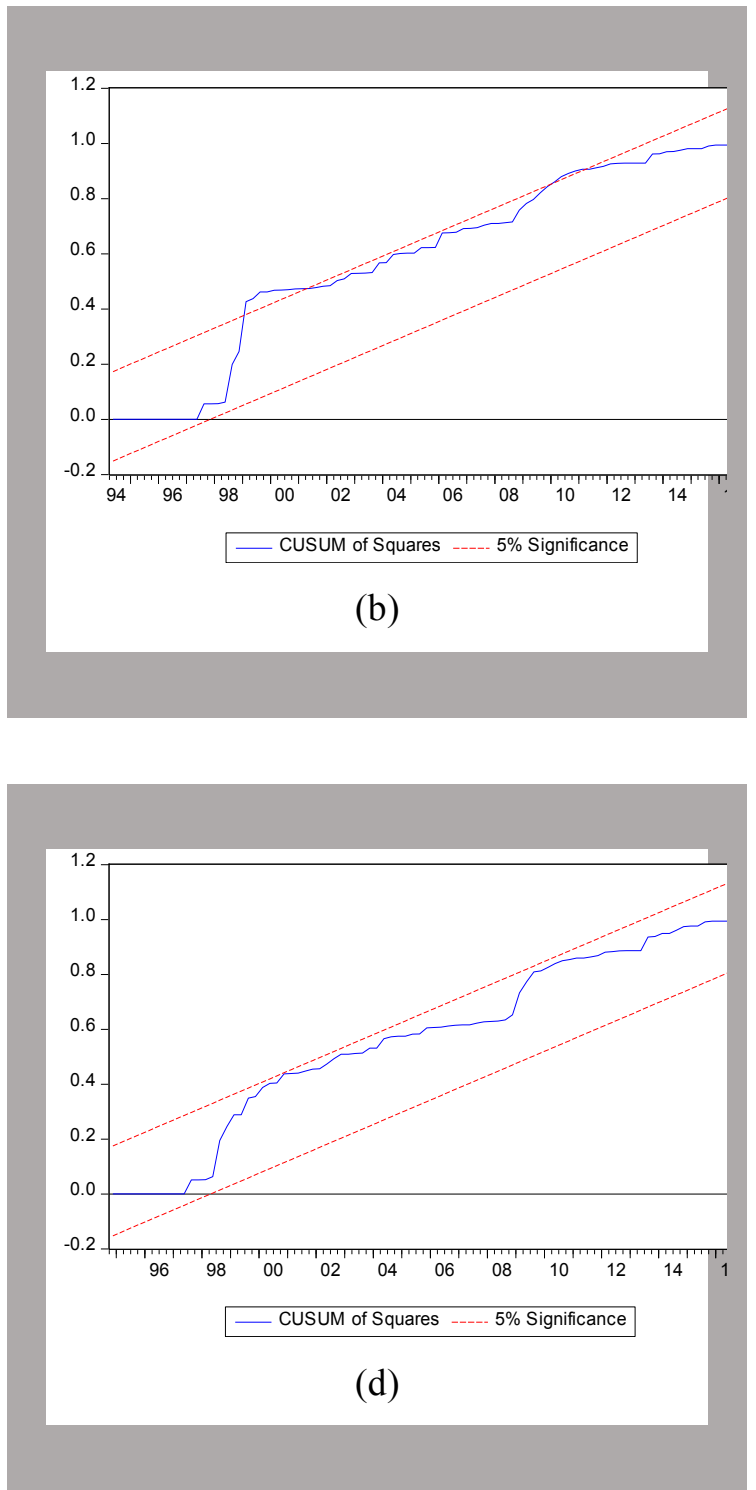

(a) CUSUM test result and (b) CUSUMQ test result of Flexible Price Model; (c) CUSUM test result and (d) CUSUMQ test result of Sticky Price Model. 